\title{
EFFECTS OF PSYCHO-EDUCATIONAL PROGRAM ON MENTALLY ILL PATIENT'S STIGMA AND SELF ESTEEM ${ }^{1}$ Shaimaa Abd Elbaset Hamed Awad, ${ }^{2}$ Sanaa Habashy Abd-EImageed, ${ }^{3}$ El Saied Saleh Hosien Saleh, ${ }^{3}$ Mohamed Adel Elhadidy. \\ ${ }^{1}$ Psychiatric and Mental Health Nursing Department, Faculty of Nursing-Mansoura University ${ }^{2}$ Psychiatric and Mental Health Nursing Department, Faculty of Nursing- Alexandria University \\ ${ }^{3}$ Psychiatric Medicine Department, Faculty of Medicine - Mansoura University E-mail of the corresponding author: Shaimaa Abd Elbaset Hamed Awad sh.psych2020@gmail.com shimaaawad@mans.edu.eg
}

\begin{abstract}
Stigma is a key problem for individuals with mental illness, which is a negative label through which the community reacts adversely towards the mentally ill. Persons with mental illness may internalize mental illness stigma and experience diminished self-esteem and self-efficacy so this study aims to assess the impact of psycho-educational Program on mentally ill patient's stigma and self-esteem. It has been carried out using a quasiexperimental research design. The subjects were constituted of 50 psychotic patients divided into 25 study group and 25 control groups from in-patient Psychiatric Department of Mansoura University Hospital. In order to collect the necessary information for the study structure interview sheet was used to collect data. Data collection was conducted during the period from February 2017 to July 2017. There was a significant positive correlation between internalized stigma and externalized stigma also there was a significant negative correlation between self-esteem, internalized stigma and externalized stigma so it is important to continue stigma psycho-educational program to overcome its negative consequences.
\end{abstract}

Keywords: self-esteem; internalized stigma; externalized stigma; psycho-educational; Program

\section{Introduction:}

Many people with serious mental illness are challenged doubly. On one hand, they fight with the symptoms and disabilities that result from the disease. On the other hand, they are confronted by the stereotypes and prejudice that result from misconception about mental illness. As a result of both people with mental illness are deprived of the opportunities that define a quality life: good jobs, safe housing, satisfactory health care, and relationship with a different group of people. [1].Undoubtedly stigma is considered a major problem to mental health issues as it pushing mentally ill patients toward isolation, limit employability, decrease life chances and hinder their right to live with dignity. Furthermore low self-esteem, hopelessness and worthlessness And it deters the public from seeking and wanting to pay for care. Worst of all, it often causes patients with mental illnesses to become so shameful to keep away from sight of any one to avoid negative consequences of stigma - and avoid seeking the treatment, services, and supports they need to be deserved. [2] Therefore, reducing stigma of mental illness is a critical step in prevention and early intervention for mental illness and the most common type of intervention strategy was psycho-education or Psychoeducation combined with cognitive restructuring which are helpful if it is worked in group because it gives the patient the opportunity to disclose the negative consequences of stigma as it provide ventilation and meditation of all 
kinds of distressing ideas.[3] so psychological intervention is very effective as it mitigate stigma, inspire hope and continue effective life goals. [4].

These stigma and discrimination reduction (SDR) initiatives can involve a variety of components, such as training, education, media campaigns, contact with people with mental illness, or combinations of these strategies. [5]. Thus, it is important to assess the impact of psycho-educational Program on mentally ill patient's stigma and self-esteem to continue up to date knowledge to eradicate stigma of mental illness.

\section{Aim of the study:}

To assess the impact of psychoeducational Program on mentally ill patient's stigma and self-esteem.

\section{Subjects and Method:-}

\section{Study Design:-}

A quasi-experimental research design was used in this study.

\section{Setting:-}

The study was carried out in the inpatient psychiatric department of Mansoura university hospital

Subjects: The subjects of the study composed of 50 psychotic patients that were selected from the above setting. They fulfilled the following inclusion criteria:

Suffering from internalized, externalized stigma and low self-esteem

- Age from 20-50 years

- Sex : both sex

- Diagnosed for at least one year with psychiatric disorder and were able to communicate coherently.

- Willing to participate in the program of the study.

\section{Exclusion criteria:}

- Mentally retarded patients.

- Acute stage of mental illness.

- Patient with co-morbidity disease.

Sample size: The subjects of the study composed of 50 psychotic patients (25 for the study subjects and 25 for control subjects). Whatever the diagnosis he had and suffering from internalized, externalized stigma and low self-esteem and this evidence after screening of all patients in the unit at Mansoura university hospital.

Tools: the questionnaire was used to collect data, includes:

Section I: Tool (1) Socio- Demographic and clinical data structured interview schedule: It was developed by the researcher to elicit data about the studied subjects. It included 2 parts:

Part 1:-Demographic characteristics of the studied subjects as sex, age, marital status, educational level, occupation, residence" either urban or rural", income and birth order.

Part 2: clinical data as number of admission, duration of illness, beginning of illness, duration of stay in psychiatric hospital.

Section II: Rosenberg Self-Esteem Scale (ISE):The Rosenberg Self-Esteem Scale was developed by (Rosenberg, 1995). [33] It consists of 10 items, answered on a 4point Likert scale ranging from (0-3) where (strongly disagree $=0$ ) and (strongly agree $=3$ ). Where some items are reversed score for items $(2,5,6,8,9)$. The scale ranges from 0-30. Scores between 15 and 25 are within normal range; scores below 15 suggest low self-esteem.

Section III: Internalized of stigma mental illness scale (ISMI): Internalized stigma of mental illness scale ISMI developed by (Boyd, 2003) ${ }^{\text {[31]; It has been }}$ translated by (Mahmoud, N. 2010) ${ }^{[32]}$ and was used to assess internalized stigma among patients. It consists of 29- items, each items answered on a 4- point likert scale: ranging from (1-4) where (strongly disagree $=1$ ) and (strongly agree $=4)$. The scale consists of 5 subscales

1- The alienation subscale:

2- The stereotype endorsement subscale :

3-The discrimination experience subscale

4-The social withdrawal subscale

5- The stigma resistance subscale 
EFFECTS OF PSYCHO-EDUCATIONAL PROGRAM ON etc...

Section V: Externalized stigma of mental illness scale:

Stigma scale developed by (King et al, 2007) ${ }^{[30]}$. It has been translated by (Hamed , 2014) ${ }^{\text {[29] }}$ It consists of 28 items with three subscales the first is discrimination (Dc) that consists of 12 statements, the second is disclosure (D) that consists of 11 statements, and the last is positive aspects (P) that consists of 5 sentences.

\section{Ethical consideration:}

- The purpose of the research was explained to all patients included in the study.

- Patient's oral consent to participate in the study was obtained.

- Patient's privacy was always respected.

- Confidentiality was ensured and the patient's right to withdrawn from the research at any time was explained and ensured.

\section{Statistical analysis:}

- Data were investigated by SPSS version 21. The data normality was firstly tested by one-sample "ShapiroWilk test".

- Qualitative data were presented using number and percentage. Correlations between the studied variables were tested using "Chi-square test". When more than $25 \%$ of the cells have expected count less than 5, "Fisher exact test" was used.

- Fisher's Exact Test, Pearson ChiSquare, and Monte Carlo test were used to test statistical significant difference between the study and the control group.

- Continuous variables were described using "Mean \pm SD (standard deviation)" for parametric data and "Mean rank" for non-parametric data. The study and control group data were compared using "Paired Sample t test" (parametric data) to compare means within one group. and "Mann-Whitney test" (non-parametric data). Analysis Of Variance (ANOVA test- F-test) used for comparison of means of more than two groups. Pearson correlation used for correlation between continuous data.

\section{Results:}

Table (1) shows frequency distribution of the study and control groups according to their socio-demographic characteristics. It appears from the table that, female patients represented a higher percentage in two groups; $(60.0 \%$ in study groups and $56.0 \%$ in control groups). Also, it was shown that more than one third of the study group was in the age group of 20 to less than 30 years, while the control groups the highest percentage were in the age groups of 30 to less than 40 years, with a mean age of $34.36 \pm 9.691$ for studied group and $35.32 \pm 7.559$ for control group. In relation to marital status, $48.0 \%$ in the study group were married compared to $52.0 \%$ in the control group. Concerning educational level, $40.0 \%$ of the study groups had a technical school compared to $36.0 \%$ in the control group, $24.0 \%$ and $40.0 \%$ of the study and control group had university degree level of education with no statistical significant differences between the two groups $(\mathrm{P}=.495)$.

Concerning occupation, it was found that nearly two third of study and control group were unemployed. Regarding residence, $56.0 \%$ of the study groups were living in rural areas, while $56.0 \%$ of the control groups were living in urban areas.

Probing for family history of mental illness nearly half of the study group had family history of mental illness in contrast nearly two third of the control group hadn't history of mental illness.

No statistical significant differences were found between the study and control group in relation to all socio-demographic characteristics, which mean that the two groups were matched in this respect. 
Table (1) Distribution of the studied patients according to their socio-demographic characteristics

\begin{tabular}{|c|c|c|c|c|c|c|}
\hline \multirow{2}{*}{$\begin{array}{c}\text { Socio-demographic } \\
\text { Items }\end{array}$} & \multicolumn{2}{|c|}{$\begin{array}{l}\text { Study group } \\
(\mathrm{No}=25)\end{array}$} & \multicolumn{2}{|c|}{$\begin{array}{c}\text { Control group } \\
(\mathrm{No}=25)\end{array}$} & \multirow[t]{2}{*}{$\mathbf{X}^{2}$} & \multirow[t]{2}{*}{ p-value } \\
\hline & No & $\%$ & No & $\%$ & & \\
\hline \multicolumn{7}{|l|}{ Sex } \\
\hline Male & 10 & 40 & 11 & 44 & \multirow[b]{2}{*}{0.082} & \multirow[b]{2}{*}{1.000} \\
\hline Female & 15 & 60 & 14 & 56 & & \\
\hline \multicolumn{7}{|l|}{ Age(in years) } \\
\hline $20:<30$ & 10 & 40 & 7 & 28 & \multirow{3}{*}{23.333} & \multirow{3}{*}{.500} \\
\hline $30:<40$ & 7 & 28 & 11 & 44 & & \\
\hline $40: 50$ & 8 & 32 & 7 & 28 & & \\
\hline Mean \pm SD & \multicolumn{4}{|c|}{$\begin{array}{l}34.36 \pm 9.691 \\
35.32 \pm 7.559\end{array}$} & & \\
\hline \multicolumn{7}{|l|}{ Marital status } \\
\hline Single & 10 & 40 & 8 & 32 & \multirow{5}{*}{3.262} & \multirow{5}{*}{0.515} \\
\hline Married & 12 & 48 & 13 & 52 & & \\
\hline Widow & 1 & 4 & 0 & 0 & & \\
\hline Divorced & 2 & 8 & 2 & 8 & & \\
\hline Separated & 0 & 0 & 2 & 8 & & \\
\hline \multicolumn{7}{|l|}{ Educational level } \\
\hline $\begin{array}{l}\text { Illiterate, Read and } \\
\text { write }\end{array}$ & 2 & 8 & 2 & 8 & \multirow[t]{5}{*}{5.386} & \multirow[t]{5}{*}{0.495} \\
\hline $\begin{array}{l}\text { Primary\& } \\
\text { Secondary }\end{array}$ & 3 & 12 & 0 & 0 & & \\
\hline Technical & 10 & 40 & 9 & 36 & & \\
\hline Institute & 4 & 16 & 4 & 16 & & \\
\hline University & 6 & 24 & 10 & 40 & & \\
\hline \multicolumn{7}{|l|}{ Occupation } \\
\hline Unemployed & 21 & 84 & 18 & 72 & \multirow{3}{*}{5.264} & \multirow{3}{*}{0.153} \\
\hline Gov. Employee & 1 & 4 & 6 & 24 & & \\
\hline Worker & 3 & 12 & 1 & 4 & & \\
\hline \multicolumn{7}{|l|}{ Residence } \\
\hline Urban & 11 & 44 & 14 & 56 & \multirow[b]{2}{*}{0.720} & \multirow[b]{2}{*}{0.572} \\
\hline Rural & 14 & 56 & 11 & 44 & & \\
\hline \multicolumn{7}{|l|}{ Physical illness } \\
\hline No & 17 & 68 & 21 & 84 & \multirow[b]{2}{*}{1.921} & \multirow[b]{2}{*}{0.383} \\
\hline Yes & 8 & 32 & 4 & 16 & & \\
\hline Family history & & & & & & \\
\hline No & 11 & 44 & 15 & 60 & & \\
\hline Yes & 14 & 56 & 10 & 40 & 1.282 & 0.396 \\
\hline Income & & & & & & \\
\hline Not satisfactory & 17 & 68 & 8 & 32 & & \\
\hline satisfactory & 8 & 32 & 17 & 68 & 6.480 & 0.023 \\
\hline
\end{tabular}


Table (2): shows distribution of the studied patients according to their clinical data. It was found that $64.0 \%$ of the study group compared to $88.0 \%$ of the control group suffering from mental illness from 1-10 years.

Concerning the number of admission to psychiatric hospital, it was found that $56.0 \%$ of the study group stated that admitted to hospital from two to four times and this percentage increase to $80 \%$ for control group.

All of the study group and control group treated with antipsychotic and anticholinergic drugs but $52.0 \%$ treated with anti-manic drugs for both study and control group

While $56.0 \%$ of the study group treated with anti-anxiety comparing to $44.0 \%$ of control group who use the same drug. And $76.0 \%$ of the study group treated with anticonvulsant comparing to $72.0 \%$ of the control group.

No statistical significant differences between the two groups regarding clinical data which mean that the two groups were matched in this respect.

Table 1:- Distribution of the studied patients according to their clinical data.

\begin{tabular}{|c|c|c|c|c|c|c|}
\hline \multirow[t]{2}{*}{ Items } & \multicolumn{2}{|c|}{$\begin{array}{l}\text { Study group } \\
(\mathrm{No}=25)\end{array}$} & \multicolumn{2}{|c|}{$\begin{array}{c}\text { Control group } \\
(\mathrm{No}=25)\end{array}$} & \multirow[t]{2}{*}{$\mathbf{X}^{2}$} & \multirow[t]{2}{*}{ p-value } \\
\hline & No & $\%$ & No & $\%$ & & \\
\hline \multicolumn{7}{|c|}{ Duration of illness in years } \\
\hline $1-5$ & 8 & 32 & 11 & 44 & \multirow{4}{*}{4.058} & \multirow{4}{*}{0.255} \\
\hline $5-10$ & 8 & 32 & 11 & 44 & & \\
\hline $10-15$ & 7 & 28 & 2 & 8 & & \\
\hline morethan15year & 2 & 8 & 1 & 4 & & \\
\hline \multicolumn{7}{|l|}{ Number of admission } \\
\hline 1st time & 3 & 12 & 2 & 8 & \multirow{3}{*}{3.532} & \multirow{3}{*}{0.171} \\
\hline 2-4times & 14 & 56 & 20 & 80 & & \\
\hline More than 4 times & 8 & 32 & 3 & 12 & & \\
\hline \multicolumn{7}{|l|}{ Medication } \\
\hline Antipsychotic & 25 & 100.0 & 25 & 100.0 & ------------ & --------- \\
\hline Anti cholinergic & 25 & 100.0 & 25 & 100.0 & ----- & --------- \\
\hline Anti-manic & 13 & 52 & 13 & 52 & 0.611 & 1.000 \\
\hline Antidepressant Anti- & 4 & 16 & 5 & 20 & 0.136 & 1.000 \\
\hline anxiety & 14 & 56 & 11 & 44 & 0.396 & 0.572 \\
\hline Anti-convulsant & 19 & 76 & 18 & 72 & 0.104 & 1.000 \\
\hline
\end{tabular}

Table 3:- This table shows Self-esteem mean score of study group pre post and follow up of the program. There was a significant difference between the mean score of self-esteem pre, post and follow up of the study. In addition, there was a significant difference among all times of assessment 
Shaimaa Abd Elbaset Hamed Awad et. al.

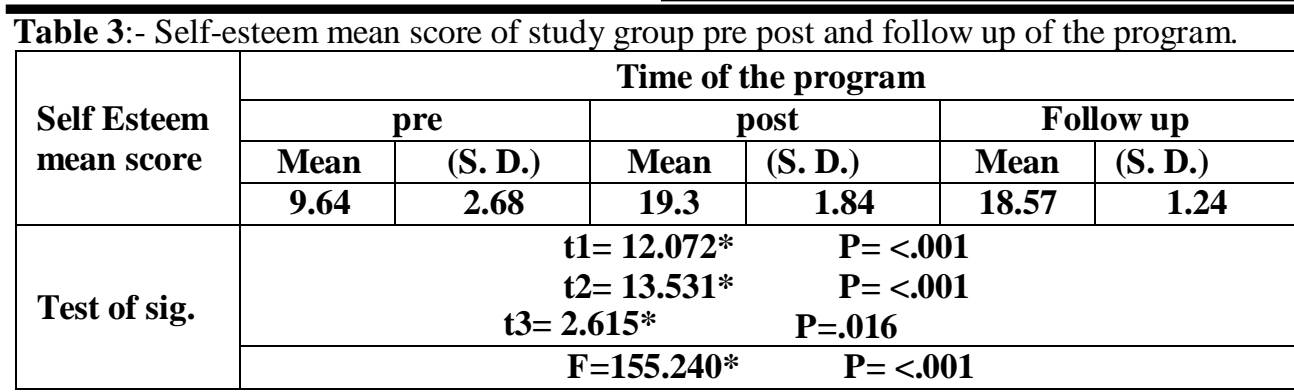

$\mathrm{t} 1=$ paired sample $\mathrm{t}$-test for mean difference pre and post

$\mathrm{t} 2=$ paired sample $\mathrm{t}$-test for mean difference pre and follow up the program $\mathrm{t} 3=$ =paired sample t-test for mean difference post and follow up of the program $\mathrm{F}=$ difference pre, post and follow up of the program

* Sig at $5 \%$ level

No of the patient become 23 due to discharge of the patient

Table 4:- subtypes of internalized stigma mean score for study group pre, post and follow up of the program. There was a significant difference between mean score of internalized stigma stereotype, discrimination, social isolation and

.001 ) respectively pre, post and follow up of the study. Except for stereotype and resistance there was no significant difference. In addition, there was a significant difference among all total internalized stigma $(\mathrm{p}=.001-.001-.001-$

times of assessment

Table 4:- subtypes of internalized stigma mean score for study group pre, post and follow up of the program.

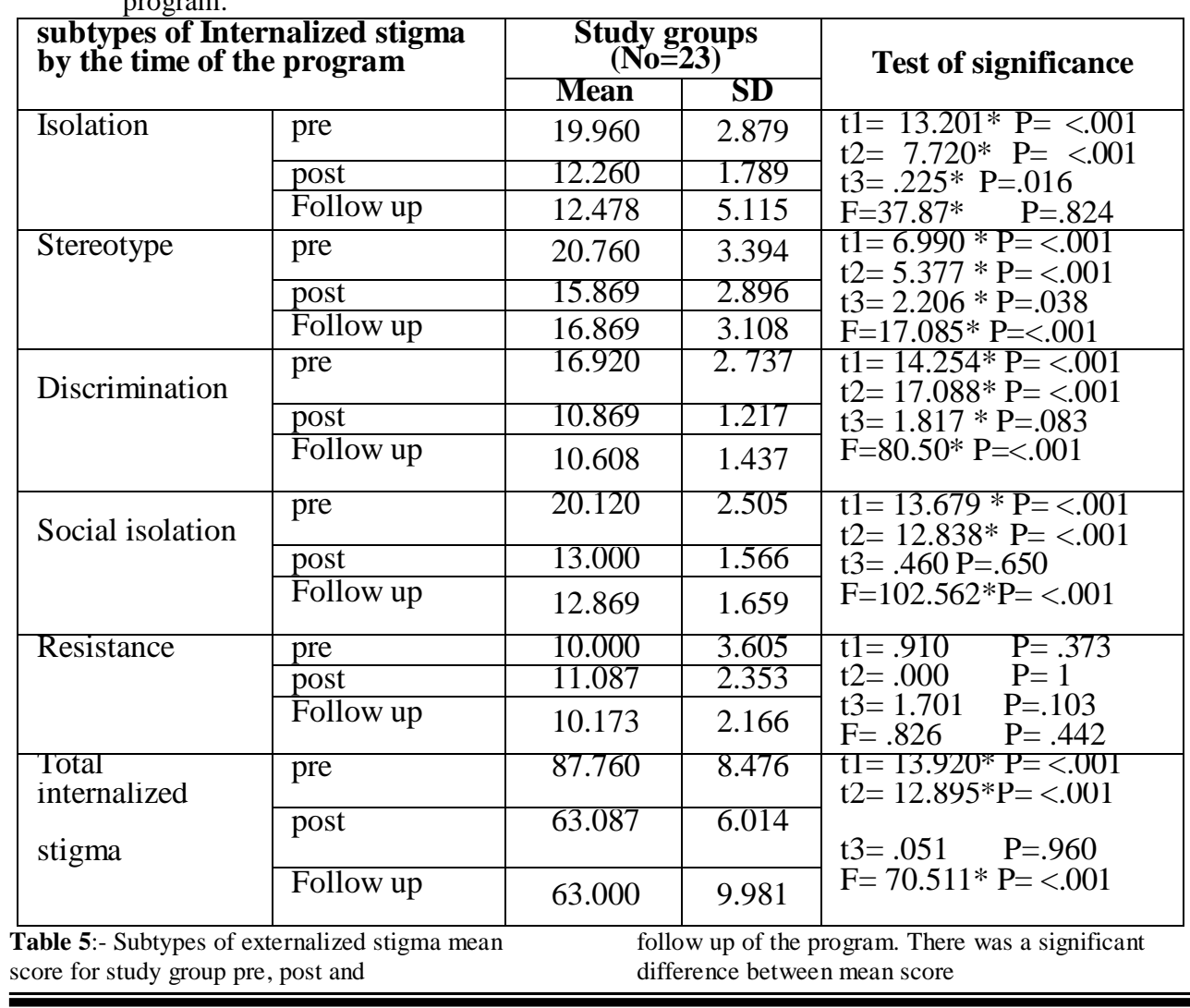


EFFECTS OF PSYCHO-EDUCATIONAL PROGRAM ON etc...

of externalized stigma discrimination, disclosure, positive aspect and total externalized stigma $(\mathrm{p}=.001)$ pre, post and follow up of the study.

Table 5: Subtypes of externalized stigma mean score for study group pre, post and follow up of the program.

\begin{tabular}{|c|c|c|c|c|}
\hline \multirow{2}{*}{\multicolumn{2}{|c|}{$\begin{array}{l}\text { Subtypes of externalized } \\
\text { stigma by the time of the } \\
\text { program }\end{array}$}} & \multicolumn{2}{|c|}{$\begin{array}{l}\text { Study groups } \\
\quad(\mathrm{No}=23)\end{array}$} & \multirow[t]{2}{*}{ Test of significance } \\
\hline & & Mean & SD & \\
\hline \multirow[t]{3}{*}{ Discrimination } & pre & 41.640 & 4.261 & \multirow{3}{*}{$\begin{array}{l}\mathrm{t} 1=29.097 * \mathrm{P}=<.001 \\
\mathrm{t} 2=21.953 * \mathrm{P}=<.001 \\
\mathrm{t} 3=5.038 * \mathrm{P}=<.001 \\
\mathrm{~F}=198.572 * \mathrm{P}=<.001\end{array}$} \\
\hline & post & 15.434 & 4.154 & \\
\hline & Follow up & 20.826 & 5.637 & \\
\hline \multirow[t]{3}{*}{ Disclosure } & pre & 34.800 & 5.212 & \multirow{3}{*}{$\begin{array}{l}\mathrm{t} 1=13.327 * \mathrm{P}=<.001 \\
\mathrm{t} 2=15.112^{*} \mathrm{P}=<.001 \\
\mathrm{t} 3=1.344 * \mathrm{P}=.193 \\
\mathrm{~F}=108.685 * \mathrm{P}=<.001\end{array}$} \\
\hline & post & 15.304 & 5.447 & \\
\hline & Follow up & 16.347 & 4.259 & \\
\hline \multirow[t]{3}{*}{ Positive aspect } & pre & 21.680 & 3.051 & \multirow{3}{*}{$\begin{array}{l}\mathrm{t} 1=23.77 * \mathrm{P}=<.001 \\
\mathrm{t} 2=16.333 * \mathrm{P}=<.001 \\
\mathrm{t} 3=2.761 * \mathrm{P}=.011 \\
\mathrm{~F}=119.821 * \mathrm{P}=<.001\end{array}$} \\
\hline & post & 8.521 & 2.889 & \\
\hline & Follow up & 9.374 & 3.613 & \\
\hline \multirow{3}{*}{$\begin{array}{l}\text { Total } \\
\text { externalized } \\
\text { stigma }\end{array}$} & pre & 98.120 & 11.42 & \multirow{3}{*}{$\begin{array}{l}\mathrm{t} 1=21.899 * \mathrm{P}=<.001 \\
\mathrm{t} 2=25.87 * \mathrm{P}=<.001 \\
\mathrm{t} 3=6.085 * \mathrm{P}=<.001 \\
\mathrm{~F}=183.02 * \mathrm{P}=<.001\end{array}$} \\
\hline & post & 39.260 & 11.87 & \\
\hline & Follow up & 46.521 & 10.64 & \\
\hline
\end{tabular}

Table 6:- this table shows that there was no significant difference in the mean of self-esteem between study and control group before implementing the program $(\mathrm{p}=0.277)$.

Table 6:- comparisons between self-esteem mean score of the study and control groups during pre, one month and three months after the program

$\mathrm{t}=$ Independent samples test

\begin{tabular}{|c|c|c|c|c|c|c|}
\hline \multirow{3}{*}{$\begin{array}{l}\text { Time of the } \\
\text { program }\end{array}$} & \multicolumn{6}{|c|}{ self-esteem mean score } \\
\hline & \multicolumn{2}{|c|}{$\begin{array}{l}\text { Study groups (No } \\
=23)\end{array}$} & \multicolumn{2}{|c|}{$\begin{array}{c}\text { Control groups } \\
(\mathrm{No}=\mathbf{2 3})\end{array}$} & \multicolumn{2}{|c|}{ Test of significance } \\
\hline & Mean & SD & Mean & SD & $\mathbf{t}$ & $\mathbf{p}$ \\
\hline $\begin{array}{l}\text { Before the } \\
\text { study }\end{array}$ & 9.640 & 2.675 & 8.840 & 2.461 & 1.100 & 0.277 \\
\hline $\begin{array}{l}\text { After one } \\
\text { month }\end{array}$ & 19.304 & 1.844 & 9.640 & 3.251 & 12.514 & 0.000 \\
\hline $\begin{array}{l}\text { after three } \\
\text { month }\end{array}$ & 18.565 & 1.236 & 8.869 & 2.563 & 16.335 & 0.000 \\
\hline
\end{tabular}

Table 7:- this table shows that there was no significant difference in mean of Internalized stigma isolation, stereotype, discrimination, social isolation and
In addition, there was a significant difference among all times of assessment

While the results reveal that there was highly significant difference between study and control group one month and three months after the program. $(\mathrm{P} \leq 0.000)$. resistance and total internalized stigma between study and control group before implementing the program $\mathrm{p}=(0.887$, $0.442,0.809,0.082,0.107,0.731$ )

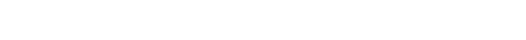


respectively. While the results reveal that there was highly significant difference between study and control group one month and three months of implementing the program in all subtypes of internalized stigma $(\mathrm{P} \leq 0.000)$. This means that there was a highly significant improvement.

Table 7:- comparisons between internalized stigma mean score of the study and control group during pre, one month and three months after applying the program

\section{Subtypes of internalized stigma by the time of the} program

\begin{tabular}{|l|}
\hline isolation \\
\end{tabular}

Before the
study

stereotype

\begin{tabular}{|l|}
\hline one month \\
\hline three month
\end{tabular}

\begin{tabular}{|l|}
\hline \multirow{4}{*}{ stereotype } \\
\cline { 2 - 2 }
\end{tabular}

\begin{tabular}{|l|c|}
\hline $\begin{array}{l}\text { Before the } \\
\text { study }\end{array}$ & 20.7 \\
\hline one month & 15.8 \\
\hline three month & 16.8 \\
\hline
\end{tabular}

\begin{tabular}{|l|l|}
\multirow{2}{*}{ social isolation } & s \\
\cline { 2 - 2 } & the \\
\cline { 2 - 2 } &
\end{tabular}
study one month

three month 10.6

\begin{tabular}{|c|c|c|c|}
\hline \multirow[t]{3}{*}{ social isolation } & $\begin{array}{l}\text { Before the } \\
\text { study }\end{array}$ & 20.12 & \\
\hline & one month & 13.00 & \\
\hline & three month & 12.87 & \\
\hline \multirow[t]{3}{*}{ resistance } & $\begin{array}{l}\text { Before the } \\
\text { study }\end{array}$ & 10.00 & \\
\hline & one month & 11.09 & \\
\hline & three month & 10.17 & \\
\hline \multirow{3}{*}{$\begin{array}{l}\text { Total } \\
\text { internalized } \\
\text { stigma }\end{array}$} & $\begin{array}{l}\text { Before the } \\
\text { study }\end{array}$ & 87.76 & \\
\hline & one month & 63.09 & \\
\hline & three month & 63.00 & \\
\hline
\end{tabular}

Table 8:- this table shows that there was no significant difference in mean of externalized stigma discrimination, disclosure and positive aspect and total externalized stigma between study and control group before implementing the program $p=(0.768,0.923,0.223,0.792)$ respectively
While the results reveal that there was significant difference between study and control group one month and after three months of implementing the program in Internalized stigma resistance $(\mathrm{P}=0.001$ 0.026 ) respectively.

\section{Internalized stigma mean score}


Table 8:- comparisons between externalized stigma mean score of the study and control groups during pre, one month and three months after applying the program.

\begin{tabular}{|c|c|c|c|c|c|c|c|c|c|c|c|c|c|c|c|c|}
\hline & \multicolumn{8}{|c|}{$\begin{array}{l}\text { Study } \\
\text { group }\end{array}$} & \multicolumn{8}{|c|}{ Control group } \\
\hline & \multicolumn{2}{|c|}{$\begin{array}{l}\text { Before } \\
\text { the } \\
\text { study }\end{array}$} & \multicolumn{2}{|c|}{$\begin{array}{l}\text { after one } \\
\text { month }\end{array}$} & \multicolumn{2}{|c|}{$\begin{array}{l}\text { after } \\
\text { three } \\
\text { months }\end{array}$} & \multicolumn{2}{|c|}{$\begin{array}{c}\text { Test of } \\
\text { Sig }\end{array}$} & \multicolumn{2}{|c|}{$\begin{array}{l}\text { before } \\
\text { the study }\end{array}$} & \multicolumn{2}{|c|}{$\begin{array}{c}\text { after one } \\
\text { month }\end{array}$} & \multicolumn{2}{|c|}{$\begin{array}{c}\text { after } \\
\text { three } \\
\text { months }\end{array}$} & \multicolumn{2}{|c|}{$\begin{array}{c}\text { Test of } \\
\text { Sig }\end{array}$} \\
\hline & $\mathbf{N}$ & $\%$ & $\mathbf{N}$ & $\%$ & $\mathbf{N}$ & $\%$ & $\mathbf{X}^{2}$ & $\mathbf{p}$ & $\mathbf{N}$ & $\%$ & $\mathbf{N}$ & $\%$ & $\mathbf{N}$ & $\%$ & $\mathbf{X}^{2}$ & $\mathbf{p}$ \\
\hline Minim al & 0 & $0 \%$ & 8 & $34.78 \%$ & 10 & $43.48 \%$ & $\begin{array}{c}60.3 \\
3\end{array}$ & .000 & 0 & $0 \%$ & 0 & $0 \%$ & 0 & $0 \%$ & 6.274 & .390 \\
\hline Mild & 0 & $0 \%$ & 15 & $65.22 \%$ & 10 & $43.48 \%$ & & & 0 & $0 \%$ & 3 & $13.04 \%$ & 0 & $0 \%$ & & \\
\hline Moderate & 15 & $65.22 \%$ & 0 & $0 \%$ & 3 & $13.04 \%$ & & & 16 & $69.57 \%$ & 14 & $60.87 \%$ & 16 & $69.57 \%$ & & \\
\hline severe & 8 & $34.78 \%$ & 0 & $0 \%$ & 0 & $0 \%$ & & & 7 & $30.43 \%$ & 6 & $26.09 \%$ & 7 & $30.43 \%$ & & \\
\hline
\end{tabular}

Table (9): Relation between levels of internalized stigma before the study, one month and three months after implementing the program between study group and control group.

\begin{tabular}{|c|c|c|c|c|c|c|c|}
\hline \multirow{3}{*}{\multicolumn{2}{|c|}{$\begin{array}{l}\text { Subtypes of externalized } \\
\text { stigma by the time of the } \\
\text { program }\end{array}$}} & \multicolumn{6}{|c|}{ Externalized stigma mean score } \\
\hline & & \multicolumn{2}{|c|}{$\begin{array}{c}\text { Study groups(No } \\
=23)\end{array}$} & \multicolumn{2}{|c|}{$\begin{array}{c}\text { Control groups(No } \\
=23)\end{array}$} & \multicolumn{2}{|c|}{ Test of significance } \\
\hline & & \multirow{2}{*}{$\begin{array}{l}\text { Mean } \\
41.640\end{array}$} & \multirow{2}{*}{$\begin{array}{r}\text { SD } \\
4.261\end{array}$} & \multirow{2}{*}{$\begin{array}{l}\text { Mean } \\
41.240\end{array}$} & \multirow{2}{*}{\begin{tabular}{|r|} 
SD \\
5.230
\end{tabular}} & \multirow{2}{*}{$\begin{array}{c}\mathbf{t} \\
0.296\end{array}$} & \multirow{2}{*}{$\begin{array}{c}\mathbf{p} \\
0.768\end{array}$} \\
\hline discrimination & $\begin{array}{l}\text { Before } \\
\text { the } \\
\text { study }\end{array}$ & & & & & & \\
\hline & $\begin{array}{l}\text { one } \\
\text { month }\end{array}$ & 15.434 & 4.154 & 39.320 & 6.998 & -14.218 & 0.000 \\
\hline & $\begin{array}{l}\text { three } \\
\text { month }\end{array}$ & 20.826 & 5.637 & 41.434 & 5.383 & -12.678 & 0.000 \\
\hline \multirow[t]{3}{*}{ disclosure } & $\begin{array}{l}\text { Before } \\
\text { the } \\
\text { study }\end{array}$ & 34.800 & 5.212 & 34.920 & 3.315 & -0.097 & 0.923 \\
\hline & $\begin{array}{l}\text { one } \\
\text { month }\end{array}$ & 15.304 & 5.447 & 33.640 & 4.590 & -12.645 & 0.000 \\
\hline & $\begin{array}{l}\text { three } \\
\text { month }\end{array}$ & 16.347 & 4.259 & 35.043 & 3.430 & -16.393 & 0.000 \\
\hline \multirow[t]{3}{*}{ positive aspect } & $\begin{array}{l}\text { Before } \\
\text { the } \\
\text { study }\end{array}$ & 21.680 & 3.051 & 22.840 & 3.578 & -1.233 & 0.223 \\
\hline & $\begin{array}{l}\text { one } \\
\text { month }\end{array}$ & 8.521 & 2.889 & 21.800 & 4.203 & -12.644 & 0.000 \\
\hline & $\begin{array}{l}\text { three } \\
\text { month }\end{array}$ & 9.374 & 3.613 & 22.956 & 3.686 & -12.644 & 0.000 \\
\hline \multirow[t]{3}{*}{$\begin{array}{l}\text { Total } \\
\text { externalized } \\
\text { stigma }\end{array}$} & $\begin{array}{l}\text { Before } \\
\text { the } \\
\text { study }\end{array}$ & 98.120 & 11.42 & 99.000 & 12.05 & -0.265 & 0.792 \\
\hline & $\begin{array}{l}\text { one } \\
\text { month }\end{array}$ & 39.260 & 11.86 & 94.760 & 15.67 & -13.738 & 0.000 \\
\hline & $\begin{array}{l}\text { three } \\
\text { month }\end{array}$ & 46.521 & 10.64 & 99.434 & 12.43 & -15.510 & 0.000 \\
\hline
\end{tabular}

Table (9): this table shows that there was a statistical significant difference between levels of internalized group before the study, one month after the study and stigma among study 
Before the study all the study groups was moderate and sever level of internalized stigma $(65.22 \%-34.78 \%)$ respectively After one month of implementing the program the study group starts to have either mild or minimal internalized stigma $(34.78 \%-65.22 \%)$ respectively

When assessing the internalized stigma after three months the percentage of minimal, mild, moderate level is $(43.48 \%$ $43.48 \%-13.04 \%$ ) respectively

There was no significant difference between levels of internalized stigma among control group before the study, one month after the study and three months after the study.4-category method are used:

1.00-2.00: minimal to no internalized stigma

2.01-2.50: mild internalized stigma

2.51-3.00: moderate internalized stigma

3.01-4.00: severe internalized

stigma

\section{Discussion:}

Patients with serious mental disorder are challenged doubly. On one hand, they fight with the symptoms and disabilities that result from the disease. On the other, they are challenged by the stereotypes and prejudice that result from misconceptions about mental illness(Corrigan \& Watson, 2002) [1]. As a result of these, Psychological interventions for seriously mental ill patients typically emphasizing on psycho-social aspects, stressing on symptom reduction, and apply cognitive behavioral techniques improving psychosocial aspects that cause combating internalized stigma. Cognitive approaches help to modify thoughts of internalized stigma and diminish self-stigma by improving empowerment through detecting life goals, nurturing assets, and constructing individual abilities. (Larson \& Corrigan, 2010) ${ }^{[6]}$.

(Knight, Wykes, \& Hayward, 2006) [7] mentioned that a cognitive-behavioral therapy held in group focuses on internalized stigma improve self-esteem so this study aims to assess the impact of stigma psycho-educational Program on mentally ill patient's internalized, externalized stigma and self-esteem. . This discussion will comprehend all aspects of the results starting from the sociodemographic data up to the effect of the intervention.

The present study showed that more than one third of the study group was in the age group of 20 to less than 30 years with a mean age of $34.36 \pm 9.691$ years. But the improvement in self-esteem, internalized and externalized stigma appear in the age group of 40 to less than 50 years this may be due to increase coping to stressful event and ability to see one self in a positive way with ageing and this is in contrast to (Sirey, Franklin, McKenzie, Ghosh, \& Raue, 2014) ${ }^{[8]}$ points of view as they mentioned that the interrelation of gender, race, anticipated stigma and a successful mental health referral illustrate the compounded barriers to mental health care for diverse older adults as they viewed seeking mental health services as a form of weakness.

The present study also showed that the majority of patients in study and control group were females $(60.0 \%$ in study groups and $56.0 \%$ in control groups) but the improvement in self-esteem, internalized and externalized stigma appears highly in male than female patients it may be due to male were highly responsive and attached to the psychoeducational program plan as they present in the hospital, trying to seek help to manage their responsibilities, masculinity and male appropriate behaviors outside their homes and this is similar to (Koken, J. and Bimbi, D. 2014) ${ }^{[9]}$ that female sex has been found to be highly suffering of mentally health problems, also the point of view of (Nemoto et al., 2011) ${ }^{[10]}$ that mention $64 \%$ of female try to commit suicide. Another Studies by (Nemoto et al, 
EFFECTS OF PSYCHO-EDUCATIONAL PROGRAM ON etc...

2015) ${ }^{110]}$ that match this current study in that stigma attitude more in females as they affected by; trans-phobia; discrimination; isolation; less or passive coping skills so female patient not improved like male gender.

Our results actually match the result of (Wahto \& Swift, 2015) [11] who concluded that men hold more negative attitudes toward psychological help seeking than women.

Similarly (Asrat, Ayenalem, \& Yimer, 2018) [12] mentioned that there was a positive significant correlation between internalized stigma and gender. There was evidence that suggests being female is a risk factor for the development or exacerbation of mental health conditions. It is believed that females are more stigmatized than males for the same behavior. They may have limited marriage invitation by males because of their illness. Therefore, such kinds of rejection and public stigma may negatively influence internalized stigma. However several kinds of literature claimed that there is no significant association between socio-demographic variables including gender and internalized stigma M. L. West, et al (2011) and J. D. Livingston et al (2010) ${ }^{[13] \&[14]}$

In contrast to (Mahmoud \& Zaki, 2015)

[15] they mentioned schizophrenic male patients are more in both groups, unemployed and their age group between $35-<45$ years as the disease process, and nature of mental illness manifestation that decrease patients ability to achieve daily life activity. Also contrast to (Ghanean, et al, 2011) ${ }^{[16]}$ they concluded that the male patients were almost and not working also contrast to (Assefa et al ,2012) ${ }^{[17]}$ they infer that male patient represent the highest group with age from 25 to 45 years but similar to the present study in that patient were unemployed. The nearly two third of the sample are unemployed this may be related to effect of mental illness such as discrimination, stereotype, prejudice and labeling process in work place lead to reduce patient ability to sustain in work.

(Yoshii, Akazawa, \& Saito, 2016) [18] mentioned that self-stigma affect negatively on patients life as they were isolated, not mention any thing about their illness to colleagues, not mentioning mental illness as a reason for unemployment and not working for a living. So it is necessary to improve working environments to ensure that people with mental illnesses can work by introducing anti-stigma countermeasures. This were contrast to this current study as there was a significant difference between mean score of externalized stigma discrimination, disclosure, positive aspect and total externalized stigma $(\mathrm{p}=.001)$ pre, post and follow up of the study therefore the program help in improvement of externalized and internalized stigma also the current study had found that the least mean score of internalized and externalized stigma was for worker patients pre-program and decreased immediately post and three months after program so the worker patient were highly improved this may be due to those working patients have no time to think about discrimination, stereotype attitude and negative consequences of stigma.

In addition, higher percentages of patients were lived in rural areas and this is consistent to the study of (Luka, 2017) ${ }^{[19]}$ who mentioned that Stigma is especially significant problem among parents in rural regions these may return to that in rural area there was an association between families and there was a disclosure of everything so the patient is seen as a shame for all of the family and also the mental illness is the fault of the family. But the improvement in the current study is for patient live in urban area as mentioned in the current study the least mean score of internalized, externalized 
stigma was for patient lived in urban areas during pre, immediately post and three months after program this may be due to the patient is away from discrimination, disclosure and stereotyped attitude from the surrounding social contact.

Also (Larson \& Corrigan, 2010) ${ }^{[6]}$ study consistent to the current study as they mentioned that Individuals who would like psychological care may dread seeking these care in rural areas because the members of the family and others around them in their social context will rapidly notice their situation. Patients live in rural area joined together that leads to highspeed communication so they fear from stigma and disclosure and seek services outside their location to escape shame, guilt, and different issue related to stigma and unplanned self-disclosure. Also patient resides in urban area confront with self-stigma; but they have a higher level of confidentiality and less disclosure availability and this is consistent to the current study as patients in urban area improved easily by application of stigma psycho-education program for the same reason.

In addition, higher percentages of them nearly two third have unsatisfactory income and this is consistent to the study of (Luka, 2017) who mentioned that the economic downturn in developed countries, and competition for funding in developing countries almost universally affect extremely the provision of mental health services. These may return to the Priority is given to physical illnesses without recognition of relation with mental disorders so in the current study the improvement is highly in patient who have satisfactory income as it was found that the least mean score of internalized, externalized stigma was for patients have satisfactory income patients pre-program and decreased immediately post and three months after program this may be due to whenever the patient had enough money to seek help he will have highly improvement in internalized and externalized stigma and receive high quality mental health services also the current study shows that the patients with illiterate (lower) educational level had the least mean score of externalized stigma during preimmediately post and three months after program this may be due to lower social class in the community may lead to no fear from discrimination and stereotypy.

In the current study the marital status revealed that the highest mean score of internalized, externalized stigma was for married patients pre-program, immediately post and three months after program this means that marriage add overload for the patient so they were highly stigmatized this is reverse the point of view of (Williams, Takeuchi, \& Adair, 1992) ${ }^{[20]}$ that mentioned in their paper the connection between marital status and mental illness for black people which revealed that black males and females who were widowed and separated/ divorced have higher disorder than married patients.

In the present study there was a statistical significant difference between levels of internalized stigma among study group pre, post and follow up of the program this means that the psycho-educational program is effective in decreasing level of stigma from sever to moderate, mild or minimal stigma and this was consistent to the point of view of (Ivezi, Sesar, \& Muẑini, 2017) [21] who mentioned that patients who share in group psychoeducational program have lower internalized stigma than the patients treated as usual. Also this result revealed when comparing the study group during times of program (before and after the education).

Furthermore (Roe et al. 2014) ${ }^{[22]}$ infer that group psycho-educational program with cognitive therapy lead to relieve of internalize stigma, enhancing self-esteem 
and quality of life when comparing the study with control group and study group during pre and post treatment.

(Štrkalj-Ivezić 2011 and Štrkalj-Ivezić 2013) ${ }^{[23] \&[24]}$ assumed that psychoeducational program about stigma and mental illness lead to reduction of internalized stigma, reduction of discrimination, stereotype and prejudice and enhance self-esteem hence patient with schizophrenia diagnosis may encounter with stereotype, false perception of feeble personality, dangerousness and incompetence which affect self-image and reduce the patient self-esteem this is relevant to the current study that reveal that there was a highly significant difference between the mean-score of selfesteem pre, post and follow up after application of the stigma psychoeducational program this may be due to disclosing the personal matter in a group psycho-education assist in relieving negative thoughts therefore enhancing self-esteem.

(Štrkalj-Ivezić 2013) ${ }^{[24]}$ mentioned that Group psycho-education program lead the decrease in the level of self-stigma of the study group and this is consistent to the current study where there was a significant difference between mean score of all levels of internalized stigma (stereotype, discrimination, social isolation and total internalized stigma) and There was a difference between mean-score of externalized stigma discrimination, disclosure, positive aspect and total externalized stigma $(\mathrm{p}=.001)$ pre, post and follow up of the study this means that the program is effective overtime but (Štrkalj-Ivezić 2013) ${ }^{[24]}$ concluded that Group psycho-education also did not influence discrimination perception and this is contrary to the current study as there was a significant difference in discrimination perception this may be due to the discrimination is the main aspect to increase perception of internalized stigma
Also (Link et al. 2001 ${ }^{[25]}$, Watson \&

River 2005) ${ }^{[26]}$ conclude that there is no relation between internalized stigma and discrimination perception and they suppose that discrimination perception not used as a dependent tool for internalized stigma but used only as awareness for presence of both stigma and discrimination. The matter is not so simple, as shown by others, who found a connection between discrimination perception and self-stigma (Brohan et al. 2010) [27] supposed the fact that discrimination perception is not only the measure of perceived discrimination as the patient may report social isolation related to defending themselves from the hurt of anticipated discrimination of others in social setting.

(Lemonis, Batinic, \& Opačić, 2014) [28] mentioned that self-stigma of mental illness correlated negatively with selfesteem (SE) and this is consistent with the current study which revealed that there was a significant negative correlation between self-esteem, internalized and externalized stigma of mental illness this show the meaning of negative correlation as if one variable increases, the other variable decreases and vice versa.

\section{CONCLUSION}

Based on the results of the present study it can be concluded that internalized, externalized stigma and self-esteem of mentally ill patients improved significantly in the study group after implementing the psycho-educational program compared to the control group.

\section{RECOMMENDATIONS}

Based on the study conclusions, it is evident that the stigma of mental illness needs strong interventions for mitigation of its effects. The following is recommended:

All patients with mental illness should be counseled and encouraged to participate in psycho-educational programs at the time of diagnosis to 
reduce unnecessary behavioral changes (discrimination, stereotype and social isolation) and internalized or externalized stigmatization perceptions.

Psycho-educational companies should be provided for all family caregivers in all clinical settings about ways to diminish stigma for patient and their family caregivers.

Increasing public awareness about the harmful consequences of mental illness stigma through mass media, taking into consideration the predisposing factors for stigma and how to attach patient with their treatment plan and raising his selfesteem.

Management of patients should move beyond symptomatic treatment to the acquirement of new concepts related to psychiatric illness and the integration between all forms of treatments.

Planning and implementation of public health awareness programs to raise the orientation toward the nature of psychiatric disorders, these programs should reach all social classes and cultures in schools, universities, social clubs, religious institutions, and mass media.

\section{References:}

[1] Corrigan, PW, and AC Watson (2002): -Understanding the Impact of Stigma on People with Mental Illness.| World Psychiatry 1(1): 1620.

http://www.ncbi.nlm.nih.gov/pmc/art icles/pmc1489832

[2] Substance Abuse and Mental Health Services Administration (2006): Developing a Stigma Reduction Initiative Center for Mental Health Services, Substance Abuse and Mental Health Services Administration, pp 1-97.

[3] McCay E, Beanlands H, Zipursky R, et al, (2007): A randomized controlled trial of a group intervention to reduce engulfment and self-stigmatisation in first episode schizophrenia. Australian eJournal for the Advancement of Mental Health 6:212-220.

[4] Mittal,D. Sullivan,G. Chekuri,L. Allee, E. Corrigan,P,W, (2012): Empirical Studies of Self-Stigma Reduction Strategies: A Critical Review of the Literature. Vol. 63 No. 10, 974- 981.

[5] Collins R, L. Wong, E, C. Cerully, J, L.Schultz, D. Eberhart N, K. (2012): Interventions to Reduce Mental Health Stigma and Discrimination. A Literature Review to Guide Evaluation of California's Mental Health Prevention and Early Intervention Initiative, pp 1-35.

[6] Larson, Jonathon E, and Patrick W Corrigan (2010): -Psychotherapy for Self-Stigma among Rural Clients.l Journal of Clinical Psychology 66(4): 430-41.

[7] Knight, M.T., Wykes, T., Hayward, P., (2006): Group treatment of perceived stigma and self-esteem in schizophrenia: a waiting list trial of efficacy. Behav. Cogn. Psychother. 34, 305-318.

[8] Sirey, J. A., Franklin, A. J., McKenzie, S., Ghosh, S., \& Raue, P. (2014): Race, stigma, and mental health recommendations among depressed older persons in aging services. Psychiatr Serv., 65(4), 537540.

https://doi.org/10.1176/appi.ps.20120 0530

[9] Koken, J. and Bimbi, D. (2014): Mental health aspects of male sex work Male sex work and society (pp. 223).

[10] Nemoto, T., Bödeker, B., and Iwamoto, M. (2011) and (2015): Social support, exposure to violence and transphobia, and correlates of depression among male-to-female transgender women with a history of 
sex work. American journal of public health, 101(10), 1980-1988.

[11] Wahto, R., \& Swift, J. K. (2015): Labels, Gender-Role Conflict, Stigma, and Attitudes Toward Seeking Psychological Help in Men. American Journal of Men's Health, 10(3), 181-191. https://doi.org/10.1177/15579883145 61491

[12] Asrat, B., Ayenalem, A. E., \& Yimer, T. (2018): Internalized Stigma among Patients with Mental Illness Attending Psychiatric Follow-Up at Dilla University Referral Hospital , Southern Ethiopia, 2018.

[13] M. L. West, P. T. Yanos, S. M. Smith, D. Roe, and P. H.Lysaker (2011): -Prevalence of Internalized Stigma among Persons with Severe Mental Illness, $\|$ Stigma Research and Action, vol. 1, no. 1, pp. 3- 10.

[14] J. D. Livingston and J. E. Boyd, (2010): -Correlates and consequences of internalized stigma for people living with mental illness: a systematic review and metaanalysis, $\|$ Social Science \&Medicine, vol. 71, no. 12 , pp. 2150- 2161 .

[15] Mahmoud, S., \& Zaki, R. A. (2015): Internalized Stigma of Mental Illness among Schizophrenic Patients and Their Families (Comparative Study). Journal of Education and Practice, 6(12), 82-98.

[16] Ghanean, H., Nojomi, M., \& Jacobsson, L. (2011): Internalized Stigma of Mental Illness in Tehran, Iran. Iran. Stigma Research and Action Stigma Research and Action, 1(1), 11-17. https://doi.org/10.5463/SRA.v1i1.10

[17] D. Assefa, T. Shibre, L. Asher, and A. Fekadu, (2012): -Internalized stigma among patients with schizophrenia in Ethiopia: a cross sectional facility-based study, $\|$ BMC Psychiatry, vol. 12, article no. 239.

[18] Yoshii, H., Akazawa, K., \& Saito, H. (2016): Stigmatization among People with Mental Illness in Japan Who Have Work Experience, (July), 1174 1184.

[19] Luka, B. (2017): Stigma and mental disorders in developmental age, 29, 906-909.

[20] Williams, D. R., Takeuchi, D., \& Adair, R. K. (1992): Marital Status and Psychiatric Disorders among Blacks and Whites. Journal of Health and Social Behavior.

[21] Ivezi, S. Ŝ., Sesar, M. A., \& Muẑini, L. (2017): Effects of a group psychoeducation program on selfstigma, empowerment and perceived discrimination of persons with schizophrenia. Psychiatria Danubina, 29(1), 66-73. https://doi.org/10.24869/psyd.2017.6 6

[22] Roe, D., Hasson-Ohayon, I., Mashiach-Eizenberg, M., Derhy, O., Lysaker, P. H., \& Yanos, P. T. (2014): Narrative En- hancement and Cognitive Therapy (NECT) Effectiveness: A Quasi-Experimental Study. Journal of Clinical Psychology, 70, 303-312. http://dx.doi.org/10.1002/jclp.22050

[23] Štrkalj-Ivezić S, (2011): Psihoza, shizofrenija, shizoafektivni poremećaj, bipolarni poremećaj. Psihoedukacija između informacije $i$ psihoterapije. Medicinska naklada, Zagreb.

[24] Štrkalj-Ivezić S (2013): Stigma in clinical practice. Psychiatr Danub; 25(Suppl 2):S200-2.

[25]Link B. (2001): Stigma as a barrier to recovery: the consequences of stigma for the self-esteem of people with mental illness. Psychiatr Serv; 52:1621-1626. 
[26] Watson A \& River L, (2005): From self-stigma to empowerment.In:

Corrigan P, editor: A Comprehensive Review of the Stigma of Mental Illness: Implications for Research and Social Change, 14164. American Psychological

Association, Washington.

[27] Brohan E, Elgie R, Sartorius N, Thornicroft G, GAMIAN-Europe, (2010): Study Group: Self-stigma, empowerment and perceived discrimination among people with schizophrenia in 14 European countries: the GAMIAN-Europe study. Schizophr Res; 122:232-8.

[28] Lemonis, E., Batinic, B., \& Opačić, G. (2014): Effects of Internalized Stigma of Mental Disorder on Quality of Life and SelfEsteem in Panic Disorder Patients. Journal of Clinical Research \& Bioethics, 5(5), 7-9. https://doi.org/10.4172/21559627.1000196

[29] Hamed Sh. (2014): Effect of stigma on self-esteem and treatment compliance among mentally ill patients and their family caregivers. Mansoura University, Unpublished Master thesis.
[30] King. M, Dinos .S, Shaw. J, Watson. R, Stevens. S, Passetti. F, Weich. S and Serfaty. M. (2007): The Stigma Scale: development of a standardized measure of the stigma of mental illness. British Journal of Psychiatry 190, 248-254.

[31] Boyd, E., ( 2003): Internalized perception of mental illness, psychometric properties of a new measure. Retrieved from: http:// repositories.cdlib.org/ postprints/ 185-2006.

[32] Mahmoud N, I. (2010): the efficacy of insight enhancement program (IEP) on improving the perception of internalized stigma and locus of control among schizophrenic patients, Cairo University, pp 1-86.

[33] Rosenberg M, Schooler C, Schoenbach C, Rosenberg F (1995): Global self-esteem and specific selfesteem. American Sociological Review; 60: 141-56 